\title{
State Council as an object of chrono-discrete mono-geography comparative law
}

\author{
Lyudmila Mkhitaryan* and Svetlana Kurakina \\ Perm State University, Bukirev st., 15, Perm, 614990, Russia
}

\begin{abstract}
The article is devoted to the analysis of the activities of the State Council in the Russian Empire and the Russian Federation. The historical stages of the creation and development of this institute in Russia are studied in detail. The activity of this state body with a fairly long pre-revolutionary history and modern constitutional status is studied from the standpoint of the chrono-discrete monogeographic method. The authors emphasize the relevance of the method used: in particular, it is indicated that its use makes it possible to trace the evolution of significant legal institutions in the position of comparative analysis. It is noted that the current stage of development of the State Council is characterized by completely new features and some contradictions, which are explored in the article. In addition to the above, it is emphasized that the history of the creation of this organ has undergone numerous changes, despite which it has retained its significance to this day, having revived in modern Russia.
\end{abstract}

\section{Introduction}

As we know, the past 2020 has become a turning point in the history of our country: this is due not only to the consequences caused by the COVID-19 coronavirus pandemic, but also to global changes in the public order caused by amendments to the Constitution of the Russian Federation.

Along with the change in the legal status of some state bodies (the Administration of the President of the Russian Federation, the Accounts Chamber), the State Council acquired a constitutional status.

\section{Results}

\subsection{Methodology of chrono-discrete monogeographic comparative jurisprudence in the study of the State Council}

The creation of the State Council in the 21st century is nothing like the revival of the "well-forgotten" old institute. From a historical and legal standpoint in the context of Russian statehood The State Council, like another state body, legal institution, or social phenomenon, can be considered based on the principles of chrono-discrete monogeographic research, and involves the use of methods of comparative analysis. Domestic history has an obvious buffer of such discretion in the formation of legal norms and the course of legal norms - the revolutionary events of 1917.

It should be noted that the object of comparison in traditional comparative jurisprudence is the legal institutions that took place in pre-revolutionary Russia and were subsequently revived in the post-Soviet space, i.e. in the Russian Federation, in connection with which the term "monogeographic" comparison is used.

By now, we can already talk about the existence of an actively developing school of chrono-discrete monogeographic comparative jurisprudence under the leadership of Professor A.A. Demichev [1].

Using this method, for example, public law and judicial institutions such as magistrates' courts, juries, the institution of bailiffs, as well as institutions of private law, criminal law institutions and principles were investigated.

\subsection{On the history of the formation of the State Council in Russia}

The State Council, established at the beginning of the 19th century at the behest of Emperor Alexander I, became a new body in the system of government bodies with special, key functions in the sphere of domestic and foreign policy of the Russian state.

The idea of creating a state body that would perform the most important advisory and organizational functions under the first person of the Russian state is not new: suffice it to recall similar Western European bodies royal councils in medieval France or the Cortes in Spain. Under Napoleon I, the Council of State became one of the most important institutions in France [2].

Researchers assess the prehistory of the appearance of the State Council in different ways: for example, the well-known pre-revolutionary historian of law M.F. Vladimirsky-Budanov notes that the State Council is a body transformed from a permanent council created in 1801. Indeed, by the decree of March 30, 1801,

Corresponding author: LMhitaryan@yandex.ru 
Alexander creates an advisory body [3], called the Council indispensable, or permanent, although in the journal of the first meeting of the members of this body, as well as in the form of an oath for council members, it is called the State [4]. Professor V.G. Scheglov [5], who devoted considerable time to the study of documents related to the organization and activities of the State Council, considers it as the embodiment of the bold plans of Peter I.

P.N. Danevsky adheres to a different point of view: he has been counting the creation of the State Council since the time of the Boyar Duma, thereby dividing the history of its formation into two periods: as a temporary institution - from ancient times to January 1, 1810, and as a permanent institution - from January 1, 1810 .

It should be recognized that in Russia since the time of the great and appanage princes there was a custom "to consult, both in legislative matters and in the most important state matters, with boyars and in general with the most noble persons in the principality" [6]. And the history of the creation of a special state institution operating on a permanent basis dates back to the first years of the power of Ivan IV. The Boyar Duma, headed by the Tsar himself, consisted of persons appointed by the highest person of the state: boyars, okolnichy and Duma nobles.

In 1722, Peter expressed an urgent need to create a legislative body. The Senate, participating as necessary in legislative activities (for example, during the emperor's absence), performed primarily administrative and supervising activities, and "could not conduct this matter (legislative process - L.M.) in a consistent course, but only participated in it, responding to random inquiries for current management needs" [4].

After the death of Peter I, attempts to create a state body with a legislative function were undertaken several times: the Supreme Privy Council - under Catherine I; The Cabinet of Ministers - under Anna Ioannovna. However, over time, these bodies assumed administrative and supervisory powers, thereby weakening the power of the Senate. After the accession to the throne of Elizabeth, the Senate was finally established as the highest state body. Under Catherine II, there was an unspoken Council, which for all 32 years of its existence bore the status of a temporary one, and its competence was never legally established.

When Alexander I ascended the throne, the system of government that he inherited after Paul had many shortcomings. Adam Czartoryski, one of the closest friends of the young emperor, noted, "The entire Russian administration was lacking before the beginning of the reforms of Alexander I order and communication; everything in her was chaos, everything was confused, nothing correct and clearly defined" [4].

To remedy the situation, Alexander, among the first acts of reformatory activity, adopts a decree on the creation of an indispensable council, established "under the special sovereign for reasoning and respecting the affairs of state." The activity of the Council is regulated by a special document - the Order - which emphasizes the legislative activity of the Council. More precisely, it is a legislative advisory, since only the emperor owns the legislative idea, and without the highest permission of the council, it is impossible to start discussing any bills. Nevertheless, Professor Shcheglov insisted on the status of the Council precisely as a legislative body, arguing that by taking away the right to interpret laws from the Senate in 1802, and the activities of the Committee of Ministers, also mentioned in Shcheglov's work, concerned only legislative activity on certain subjects of state administration, and carried exclusively episodic [5].

On January 1, 1810, the State Council began to operate, created according to the project of M.M.Speransky and was the highest legislative institution of the Russian Empire. Thus, from a "temporary and transitory" body, the State Council becomes a permanent institution. Its main functions were to discuss bills submitted by ministers with their subsequent submission for approval by the emperor, drawing up estimates and states of other state bodies and institutions, as well as considering complaints against decisions of departments of the Senate.

The structure of the State Council deserves special attention. So, initially it was formed and consisted of 35 members, who were appointed by the emperor. Subsequently, in 1905, it was transformed into the upper house of the Russian parliament, and its members were not only appointed by the emperor, but also elected from professional curiae.

Speaking about the role of the State Council in the pre-revolutionary period, it should be noted that it played one of the key roles in the publication of the Code of Laws of the Russian Empire (1832), which, by the way, was the first codified normative act in the history of Russia; its members made a significant contribution to the preparation and implementation of legislative reforms in the 1860s.

Fundamental changes in the status of the State Council took place after the constitutional reforms of 1905-1906, as a result of which this body became the upper house of the Russian parliament. The changes also affected the procedure for the formation of this body: now only half of all members of the Council were appointed directly by the emperor, the second half was elected by five curia from the Orthodox clergy, provincial noble societies, provincial zemstvo assemblies, the Academy of Sciences and universities, from the Council of Trade and Manufactures. Thus, after the changes in 1906, the legislative function in Russia began to be carried out by a bicameral parliament: the State Duma and the State Council, and bills were submitted to the emperor for approval only after the approval of the Chambers.

The February Revolution of 1917 radically changed the approach to the existence and the need for such a body: it was simply abolished, like most other institutions of the bourgeois type, objectionable to the authorities. 


\subsection{Activities of the State Council in the modern period}

The modern era of the State Council of the RSFSR period began in July 1991; its structure included the Secretary of State, advisers and ministers. Historians, as a rule, view it from the position of a body with consultative and advisory functions under the President. It did not last long: barely having time to revive after a long absence in the structure of state space, it was again abolished, thus repeating the fate of its predecessor institution. So, it was abolished by the November decrees of the President of the RSFSR, a possible reason for which was the uselessness of the council.

After a short period of time, they started talking about its creation again already in the post-Soviet state. The Council was re-formed by the Decree of the President of the Russian Federation of September 1, $2000 \mathrm{~N} 1602$ "On the State Council of the Russian Federation". For 20 years it was an advisory body under the President of the Russian Federation, and its functions were to coordinate the most important areas of policy, socio-economic development of the Russian Federation and subjects of the Russian Federation [7]. The meetings of this body were not frequent - once, maximum twice a year, and on the whole it was not of any importance in the system of the highest bodies of state power.

In 2020, the Council acquired a new, hitherto unprecedented status of a constitutional body formed by the President of the Russian Federation to ensure the coordinated functioning and interaction of bodies. They are part of the unified system of public power, determine the main directions of domestic and foreign policy of the Russian Federation and priority areas of the socioeconomic development of the state. Its activities are based on the Constitution of the Russian Federation (paragraph e5 of Article 83), Federal Law "On the State Council of the Russian Federation" No. 394-FZ, Decree of the President of the Russian Federation of December 21, 2020 No. 800 "Issues of the State Council of the Russian Federation", and a number of other acts normative content. The latter source of law allowed a completely new look at the role and place of the Council in the structure of state authorities.

The Federal Law, adopted in December 2020, allowed a completely new look at the role and place of the Council in the structure of state authorities. By the way, the very name "State Council" in the law is written with capital letters, which is important.

The head of the State Council, as in the prerevolutionary period, is the highest person of the state the President of the Russian Federation, he also appoints the members of the Council. The State Council must include the heads of the highest federal bodies of executive and legislative power, as well as heads of the highest executive bodies of state power of the constituent entities of the Russian Federation. Representatives of local self-government bodies, as well as representatives of political parties that have factions in the State Duma of the Russian Federation, are not obligatory representatives in the State Council of the Russian Federation, but can only be included in its composition by decision of the President of the Russian Federation.

For the first time, the law defines not only the tasks, but also the functions of the State Council, in particular, the main tasks of the Federal Law include: assistance in the implementation of the powers of the President on issues of ensuring the coordinated functioning and interaction of government bodies.

There is discussion of problems of particular state significance concerning the relationship between the Russian Federation and its constituent entities, the most important issues of state building and strengthening the foundations of federalism, making the necessary proposals to the President. It includes discussion of issues related to the implementation (compliance) by federal government bodies, government bodies of the constituent entities of the Russian Federation, local government bodies, their officials of the Constitution of the Russian Federation, federal constitutional laws, federal laws, decrees and orders of the President, resolutions and orders of the Government, and making appropriate proposals. There is also assistance to the President when he uses conciliation procedures to resolve disagreements between government bodies of the Russian Federation and its constituent entities, as well as between government bodies, etc.

As for the functions of the State Council, they are defined separately in Article 6, and consistently indicate the specific areas of activity of this body. Consideration of issues is related to the interaction of public authorities, discussion of the main directions of domestic and foreign policy of the Russian Federation and priority areas of socio-economic development of the state; analysis of the practice of state and municipal administration.

There is also development of proposals for their improvement; participation in determining, agreeing and approving criteria and indicators of the effectiveness of the activities of the executive authorities of the constituent entities of the Russian Federation and local self-government bodies. It covers monitoring of the values (levels) of performance indicators, planned by the constituent entities of the Russian Federation and the values (levels) achieved by them during the reporting period, etc.

\subsection{Uncertainty of the legal status of the modern State Council}

However, despite the revival of an already seemingly developed institution that existed in pre-revolutionary Russia and has proven its importance and relevance, it should be noted that the modern stage of its development is characterized by completely new features and some contradictions.

First, as noted by A.A. Kondrashev [8], the State Council puts the executive power of the constituent entities under the control of the federation, which cannot but contradict the principle of separation of powers and the structure of state power bodies of the federal and 
local levels (the level of constituent entities) of the Russian Federation.

Second, attention should be paid to the entry of the modern State Council into the structure of constitutional authorities. The fact is that the State Council, as a body, does not function fully - it is not for nothing that A.A. Kondrashev points out that the Council does not exercise its powers independently, but does so only with the participation of the head of state.

Third, one can agree with A.K. Sissakian, who argues that it is impossible to unambiguously classify the Council as a legislative or executive body of state power. Hence, formally it can either become a part of the Federal Assembly as a body of the third chamber (along with the State Duma of the Russian Federation and Federation Council of the Russian Federation), or completely replace functionally the body of the Federal Assembly of the Russian Federation [9].

In the opinion of Professor T. Ya. Khabrieva, the constitutional novel about the State Council should not be interpreted as the establishment of a new branch of state power, and the State Council should be attributed to bodies with special competence [10].

Fourth, a legal clarification is required regarding Part 2 of Article 14 of the Federal Law "On the State Council", according to which, in the event the State Council makes a decision on the need to adopt or amend a federal law. "The draft of the relevant act is submitted to the State Duma of the Federal Assembly Federation". At the same time, Article 104 of the Constitution of the Russian Federation contains a closed list of subjects of legislative initiative, among which there is no State Council [11].

These and many other disputes and objections regarding the determination of the place of the State Council in the system of state bodies cause a lot of speculation and conjecture among contemporaries. How exactly events will unfold in the political arena - we just have to find out.

\subsection{Back to basics}

Meanwhile, the significance of the revival of the State Council is also obvious, as it has proven its effectiveness in the historical development of the institution. So, in the explanatory note to the Draft Law "On the State Council of the Russian Federation", prepared in connection with the adoption of the Law of the Russian Federation on the amendment to the Constitution of the Russian Federation dated March 14, 2020 No. 1-FKZ "On improving the regulation of certain issues of the organization and functioning of public authorities", it is indicated, in particular, that the State Council is called upon to ensure coordinated interaction of state public authorities [12]. In addition, the constitutional status of this body is especially noted, which is confirmed by its appointment by the President of the Russian Federation, as well as an indication of the corresponding provision in paragraph e5 of Art. 83 of the Constitution of the Russian Federation.
The State Council, in addition to the above, will also contribute to the implementation of domestic and foreign policy of the state, defining priority areas in the development of the social and economic sphere of Russian policy.

\section{Conclusions}

Summarizing the above, it should be noted that:

1) The State Council is a body that existed in the prerevolutionary period of the development of our state. Moreover, although its role and significance were forgotten during the Soviet era, at the moment we can safely talk about its revival, of course, with the inherent signs of existing realities. In other words, identical functions and structure of the revival of this institution is a priori impossible, since at the moment the state system is at a different stage of development, has a structure of society different from the pre-revolutionary power, and, of course, a different form of state.

2) The history of the creation of the State Council should be conducted not from 1810, as is customary in modern research, but earlier, at least from 1801, the time of Alexander's creation of the Indispensable Council.

3) Researchers do not come to a single conclusion about the unambiguity of assigning the State Council to one or another branch of government, not to mention endowing it with a body of constitutional status. We believe that the State Council is rather a body with special competence, as was the opinion of Professor T. Ya. Khabrieva above. Assumptions are also made regarding the functioning of the State Council in the Russian Federation, similar to a foreign analogue operating in France.

4) In addition to what has been said, it is also necessary to mention the applicability of the methodology of chrono-discrete monogeographic comparative jurisprudence to this institution. Naturally, the difference in the specific historical conditions of the beginning and the end of the twentieth century. This is very significant, therefore, that not all aspects of the existence of the pre-revolutionary and modern State Councils can be comparable. The use of the methodology of chrono-discrete monogeographic comparative jurisprudence, developed for comparing state and legal institutions, in the existence of which, for one reason or another, has a time gap, will make it possible to develop practical recommendations for improving the current legislation based on a comparison of historical experience and modernity.

\section{References}

1. A. A. Demichev, Principles and prospects for the development of the scientific direction Chronodiscrete monogeographic comparative jurisprudence, Legal science and practice: Bulletin of the Nizhny Novgorod Academy of the Ministry of Internal Affairs of Russia, 1(33), 23-28 (2016)

2. N. M. Kasatkina, State Council (European model), Russian Law J., 12 (2003) 
3. M. F. Vladimirsky-Budanov, Review of the history of Russian law, 292 p. (2005)

4. Russia. State Council. 1801-1901: Brief sketch of activities for a hundred years of existence: Comp. in the State Office, IV, 4-9 (1901)

5. V.G. Shcheglov, State Council in Russia in the first century of its formation and activity (March 30, 1801-1901), Historical and legal sketch, 3, 18-19 (1903)

6. P. N. Danevsky, History of the formation of the State Council in Russia (Printing house of the II branch of his own E. I. V. Chancellery, 5, 1859)

7. On the State Council of the Russian Federation: Decree of the President of the Russian Federation of 09.01.2000 No. 1602, Rossiyskaya Gazeta, 172 (2000)

8. A. A. Kondrashev, Constitutional amendments 2020: on collisions and defects that give rise to irreparable conflicts between "eternal chapters" and chapters 3 - 8 of the Constitution of Russia, Constitutional and municipal law, 3 (2021)

9. A. K. Sissakyan, Constitutional transformations of the public authority system and their influence on the formation of a positive constitutional sense of justice, Constitutional and municipal law, 3 (2021)

10. T. Ya. Khabrieva, A. A. Klishas, Thematic commentary to the Law of the Russian Federation on the amendment to the Constitution of the Russian Federation of March 14, 2020 N 1-FKZ "On improving the regulation of certain issues of the organization and functioning of public authorities" (2020)

11. On the State Council of the Russian Federation: Federal Law, 394-FL, Russian newspaper, 12 (2020)

12. On improving the regulation of certain issues of the organization and functioning of public authority No. 1-FKZ on the amendment to the Constitution of the Russian Federation, Collection of legislation of the Russian Federation, 11 (2020) 